\title{
Roles of Brain-Derived Neurotrophic Factor (BDNF) In Developing Jaw
}

\author{
Noor Natik Raheem ${ }^{1}$, Mohammed Faris ${ }^{2}$,Athraa Y. Al-Hijazi ${ }^{3}$, Ali I Alqurshi ${ }^{4}$ \\ 1Oral Hisology, Researcher/ College of Dentistry, Mustansiriyah University, Baghdad, Iraq, 2Oral Physiology, \\ Researcher/ Al-Mustaqbal University College/Dentistry Department, Babylon, Iraq, ${ }^{3}$ Oral Histology, Researcher/ \\ Al-Mustaqbal University College/Dentistry Department, Babylon, Iraq, ${ }^{4}$ Dentist/ Researcher, Al-Mustaqbal \\ University College/Dentistry Department, Babylon, Iraq
}

\begin{abstract}
Brain-derived neurotrophic factor (BDNF) recognized to be involved in differentiation and proliferation of specialized cell such as osteoblast cell and endothelial cell. The study designed to identify the effect of exogenous BDNF on development of jaw and on neural marker expression.

Twenty pregnant rats, ten rats injected (I.M) with $0.1 \mathrm{ml}$ normal saline, other ten injected (I.M) with $0.1 \mathrm{ml}$ of BDNF. Rats were received three doses at intervals $(0,7,14$ day of gestation periods). The developmental jaw of embryos in $16^{\text {th }}$ and $18^{\text {th }}$ intra-uterine life studied for histological and immune-histochemical investigations.

The results Illustrated an enhancement of bone development during proceeding embryonic periods for both study groups .Moreover, the experimental group showed a significant differences in the mean of bone cell count at $18^{\text {th }}$ day in comparison to $16^{\text {th }}$ day IUL, and in comparison to control. Results revealed a positive expression of neuronal marker by proliferating nerve cells with a significant difference in comparison between experimental and control. The study suggests that BDNF may contributed in promoting the differentiation of bone cells and enhancement of bone formation with increasing in expression of neuron marker.
\end{abstract}

Key words: Brain derived neurotrophic factor, bone, embryogenesis, osteogenic cell, bone stem cell

\section{Introduction}

Neurotrophins and their receptors are important molecules that have a role in the development and maintenance of nervous organs and involved in regulating of organogenesis of skeletal tissues ${ }^{1,2}$. Studies have shown that neurotrophins are widely expressed in skeletal tissues, and shared in chondrogenesis, osteoblastogenesis, and osteoclastogenesis ${ }^{3,4}$.They illustrated to be involved in regulating skeletal tissue formation and in healing events ${ }^{5}$.Moreover ,BDNF stimulates and controls growth of new neurons from neural stem cells (neurogenesis) ${ }^{6,7}$ and BDNF protein and mRNA have been identified in

\section{Corresponding Author:}

Athraa Y. Al-Hijazi

Email: athraayms@yahoo.com most neural areas of developing tissues ${ }^{8,9}$.

This study used Brain-derived neurotrophic factor (BDNF) to investigate its potential roles on expression of neural marker in developing bone of prenatal rat jaw.

\section{Materials and Methodology}

Twenty female Albino Wister rats with age range of 4-5 months, weighted 250-270g have been enrolled in this study and according to ethical approval from the ethical committee of the Al-Mustaqbal University College (license No: 069222) authorized all of the experimental approaches. Rats were first isolated from the rest, for two weeks to exclude any previous pregnancy. After examination and confirmation of non- pregnancy by the resident veterinary doctor, each female paired with a male in a separate cage and checked daily for the presence of vaginal plug. Then 
the pregnant rats maintained in the animal department of (National Center of Drug Control and research / Iraq) under control conditions of temperature, drinking and food consumption. All experimental procedures carried out according to the ethical principles of animal experimentation. The pregnant rats divided randomly into 2 groups, each consisting of 10 animals.

Group I (control group) received $0.1 \mathrm{ml}$ normal saline by intramuscular injection

Group II (experimental group) received $0.1 \mathrm{ml}$ BDNF (ab9794)/ Abcam (intramuscular injection).Both groups received three doses at gestation interval periods $(0,7,14$ day).

Five rats from each group sacrificed at $16^{\text {th }}$ and $18^{\text {th }}$ day of gestation date and their embryo heads used for histological and immune-histochemical investigation.

\section{Histological examination}

Embryo jaw resected, fixed in $10 \%$ buffered formalin, dehydrated, and embedded in paraffin wax. Then section $(5 \mu \mathrm{m})$ stained with Hematoxylin and Eosin (H\&E). The histological examination done under light microscope by examining four microscopical fields for each slide. Mean readings of counting number of the bone mesenchymal stem cells (BMSCs), osteocytes, and osteoblast were calculated and used in statistical analysis.

\section{Immunohistochemistry investigation on tissue sections}

The Neuronal Marker (ab104224) from Abcam used and according to manufacture data sheets, the preparation and characterization of this monoclonal antibody described. Positive peroxidase staining produces brown color on light microscopy; the percentages of positively stained cells counted at five representative fields (40X). Quantification method for Immuno-response estimated for the positive cell that expressed neuronal Marker and assessed by identifying and scoring 100 cells in five fields, X40 of the examined area. The scoring is (Score 0 , none; score $1,<10 \%$; score $2,10-50 \%$; score 3, 51$80 \%$; score $4,>80 \%)^{10}$.

\section{Radiological examination}

All embryo's head radiographed by Plain X-ray before resection with standard dental radiographic film. $\operatorname{Voltage}(\mathrm{kV})=60, \operatorname{Current}(\mathrm{mA})=70, \operatorname{Exposure}(\mathrm{s})=0.08$.

\section{Statistical Analysis}

The data analyzed by using Statistical methods using SPSS software program (version 19) and including:

A. Descriptive statistics

1. Means 2. Std Dev.3. Std error 4.Min.\&Max.

B. One-way ANOVA test with multiple comparisons by (LSD Method).

\section{Results}

\section{Histological and immune-histochemical}

\section{Findings}

Control group at $16^{\text {th }}$ IUL showed new apposition of thin trabeculae surrounding by proliferating bone stem cells, and at $18^{\text {th }}$ day, histologic section showed bone trabeculae with osteoblast on the surface.

Immuno-histochemical expression of neuronal marker for embryonic bone (control\& exp.) at $16^{\text {th }} \& 18^{\text {th }}$ IUL have showed a positive DAB stain by proliferating neural cells in developing jaw, and recorded score 1 for control and score 2 with intense immune reaction for the experimental.

Experimental group at $16^{\text {th }}$ IUL showed bone trabeculae with osteoblast, and proliferating bone stem cell detected around the trabeculae. At $18^{\text {th }}$ day of gestation period, histological views illustrated well, thick organized trabeculae surrounding by osteoblast and osteocyte cell trapped inside the trabeculae. Figure (1) 

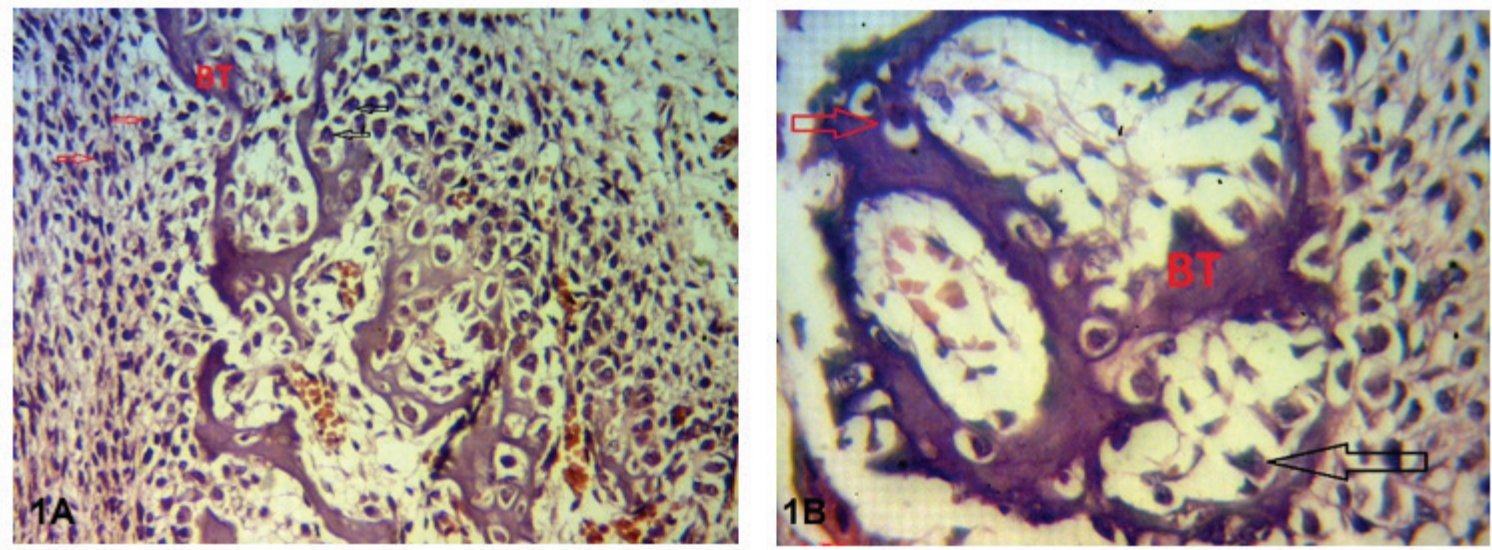

Figure (1) embryonic bone at $18^{\text {th }}$ IUL for control and experimental groups " $1 \mathrm{~A}$ : Control shows bone trabeculae (BT), bone mesenchymal stem cell.(arrows).H\&Ex20 ; 1B: Experimental shows bone trabeculae (BT); osteocyte (red arrow) osteoblast (black arrow) H\&Ex40"

\section{Radiological results}

Radiographic evaluation for the study groups of embryos at $18^{\text {th }}$ IUL illustrated that control group showed faint and streaky radio-opacity in upper and lower jaws, while experimental group has recognized more organized, linear radio-opacity in upper and lower jaws. Figure (2)

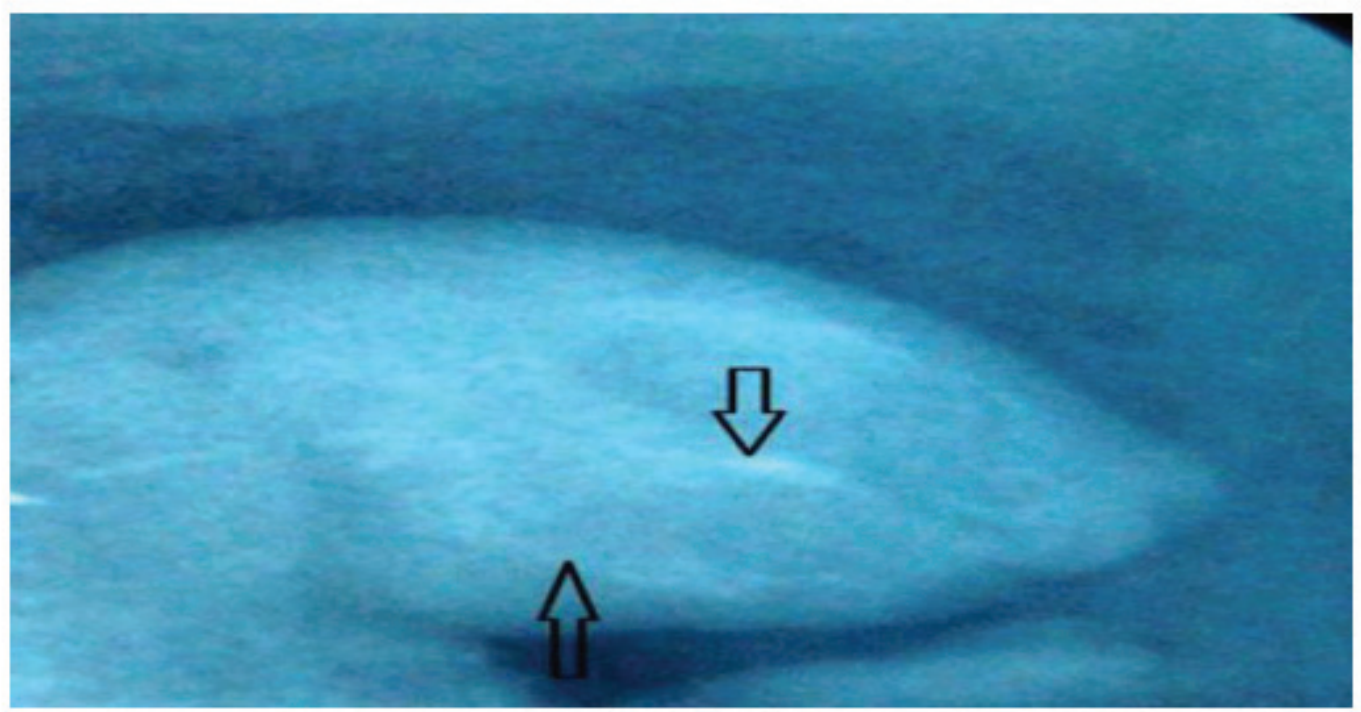

Figure (2) Linear opaque radio-density represents development of upper and lower jaw (arrows) for Experimental group at $18^{\text {th }}$ IUL

\section{Statistical Analysis}

Tables (1\&2) illustrate the mean of bone cell (osteoblast and osteocyte) with bone mesenchymal stem cells (BMSC) for control and experimental groups at the $16^{\text {th }}$ and $18^{\text {th }}$ gestation periods. Multiple comparisons by (LSD Method) of bone cells and BMSC count showed a significant value for the experimental group at the period $18^{\text {th }}$ day in comparison to $16^{\text {th }}$ day IUL, and in comparison to control at $18^{\text {th }}$ day IUL.

Table(3) illustrates mean of neuron cells that expressed positive neuron marker . The results showed a high record in the mean of positive cells in experimental for both periods in comparison to control with a 

significant difference value. On other hand, mean of positive cells in experimental group showed to be high at period $16^{\text {th }}$ in comparison to $18^{\text {th }}$ period, moreover, reversed results in control observed.

Table (1): Statistic analysis with multiple comparisons by (LSD Method) among all pairs of different (S.O.V.) effect's Parameters in compact form, for the bone cells count Parameter in studied trials.

\begin{tabular}{|c|c|c|c|c|c|c|c|c|}
\hline $\begin{array}{l}\text { Groups/ Bone } \\
\text { cells } \\
\text { /periods }\end{array}$ & $\begin{array}{l}\text { Sample } \\
\text { No. }\end{array}$ & Mean & Std. Dev. & Std. Error & $\begin{array}{l}95 \% \\
\text { L.bou }\end{array}$ & $\begin{array}{l}\text { Mean } \\
\text { bound }\end{array}$ & Min. & Ma \\
\hline $\begin{array}{l}\text { Osteoblast - } \\
\text { 16th IUL }\end{array}$ & 10 & 8.97 & 1.03 & 0.42 & 6.58 & 10.75 & 6 & 11 \\
\hline $\begin{array}{l}\text { Control - } \\
\text { Osteoblast 18th } \\
\text { IUL }\end{array}$ & 10 & 14.00 & 1.10 & 0.45 & 11.79 & 15.15 & 12 & 16 \\
\hline $\begin{array}{l}\text { Control - } \\
\text { Osteocyte -16th } \\
\text { IUL }\end{array}$ & 10 & 4.67 & 1.88 & 1.58 & 3.59 & 5.74 & 3 & 6 \\
\hline $\begin{array}{l}\text { Control - } \\
\text { Osteocyte - } \\
18 \text { th IUL }\end{array}$ & 10 & 8.87 & 2.07 & 0.84 & 6.50 & 10.83 & 7 & 12 \\
\hline $\begin{array}{l}\text { Control - } \\
\text { BMSCs 16th } \\
\text { IUL }\end{array}$ & 10 & 28 & 0.63 & 0.26 & 27.1 & 29.6 & 26 & 29 \\
\hline $\begin{array}{l}\text { Control - } \\
\text { BMSCst - 18th } \\
\text { IUL }\end{array}$ & 10 & 22 & 0.55 & 0.22 & 21.3 & 23.3 & 18 & 24 \\
\hline $\begin{array}{l}\text { Exp-Osteoblast } \\
\text { - 16th IUL }\end{array}$ & 10 & 10.70 & 1.64 & 0.67 & 9.78 & 11.22 & 9 & 12 \\
\hline $\begin{array}{l}\text { Exp-Osteoblast } \\
\text {-18th IUL }\end{array}$ & 10 & 26.88 & 0.75 & 0.31 & 24.04 & 27.62 & 24 & 28 \\
\hline $\begin{array}{l}\text { Exp-Osteocyte } \\
\text { - 16th IUL }\end{array}$ & 10 & 8.00 & 0.89 & 0.37 & 7.06 & 9.94 & 6 & 10 \\
\hline $\begin{array}{l}\text { Exp-Osteocyte } \\
\text { - 18th IUL }\end{array}$ & 10 & 12.89 & 1.83 & 0.75 & 10.91 & 13.76 & 10 & 14 \\
\hline $\begin{array}{l}\text { Exp.-BMSCs- } \\
\text { 16th IUL }\end{array}$ & 10 & 24 & 0.52 & 0.21 & 22 & 25.4 & 20 & 26 \\
\hline $\begin{array}{l}\text { Exp.- BMSCs - } \\
\text { 18th IUL }\end{array}$ & 10 & 20.5 & 0.75 & 0.31 & 19.6 & 21.7 & 19 & 22 \\
\hline
\end{tabular}

Table (2): Multiple comparisons by (LSD Method) among all pairs of different (S.O.V.) effects of Density Parameter in compact form for bone cells count

\begin{tabular}{|l|l|l|l|l|}
\hline Groups & periods & Mean Difference & Sig.(*) & C.S. \\
\hline Control /Exp. & 16 th IUL & 0.14 & 0.655 & NS \\
\hline Control/ Exp. & 18 th IUL & 0.67 & 0.007 & HS \\
\hline Control & 16 th / 18h IUL & 0.16 & 0.522 & NS \\
\hline Exp. & 16 th / 18th IUL & 0.71 & 0.0001 & HS \\
\hline
\end{tabular}


Non Sig. at $\mathbf{P}>0.0$

Table (3): Multiple comparisons by (LSD Method) among all pairs of different (S.O.V.) effects of Density Parameter in compact form for positive expression of neuron marker

\begin{tabular}{|l|l|l|l|l|l|}
\hline Groups & periods & Mean of +ve cell & Mean Difference & Sig. $(*)$ & C.S. \\
\hline Control /Exp. & 16 th IUL & $7.33 / 12.44$ & 0.16 & 0.000 & HS \\
\hline Control/ Exp & 18 th IUL & $9.34 / 8.67$ & 0.43 & 0.011 & S \\
\hline Control & 16 th / 18h IUL & $7.33 / 9.34$ & 0.22 & 0.000 & HS \\
\hline Exp. & 16 th / 18th IUL & $12.44 / 8.67$ & 0.41 & 0.000 & HS \\
\hline
\end{tabular}

Non Sig. at $\mathbf{P}>0.0$

\section{Discussion}

The study focused on jaw development of rat model and confirmed how the use of brain-derived neurotrophic factor can affect formation and aggravation of bone. However, the effect of BDNF in bone development reconsolidation has been less studied.

A studies found that neurotrophins and their receptors expressed in mouse osteoblastic cell lines ${ }^{11,12}$ .The present study shows that using of exogenous BDNF plays a role in development of the jaw as the results confirmed by histological and immune-histochemical investigations and by radiologic examination. The results show that the mean of the number of bone cell (osteoblast and osteocyte) with bone mesenchymal stem cells for experimental group are higher in comparison to control ${ }^{13,14}$.In addition, increment of expression of neuronal marker by the proliferative mesenchymal stem cell and formative bone cell enhanced bone formation 15,16 .

Furthermore, in experimental group, we observed that new bone trabeculae formation started at $16^{\text {th }}$ day proceeding the control group with a coincidence of an increment for expression in neuron marker. At $18^{\text {th }}$ day of gestation period a well, thick organized trabeculae surrounding by osteoblast with presence of osteocyte detected histologically .Moreover, the result confirmed radiologically as the radiographic view showed a linear opaque radio-dense demarcated the jaw.
The results could explained as following: BDNF is a key molecule that controls neuronal differentiation, survival and synaptic formation ${ }^{17}$ which helped in differentiation of bone cells, and enhanced neuron expression as revealed in this study.

\section{Conclusion}

Brain-derived neurotrophic factor (BDNF) has neurological and non-neurological effect on bone formation by increasing expression of neuronal marker with increment of the number of bone progenitor cells and bone forming cells.

Acknowledgment: This work was supported by Prof. Dr. Hasan Majdi, Dean of Al-Mustaqbal University College, Babylon, Iraq

Ethical Clearance: The Research Ethical Committee at scientific research by ethical approval of both $\mathrm{MOH}$ and MOHSER in Iraq

\section{Conflict of Interest: Non}

Funding: Self-funding

\section{References}

1. Mikami Y, Suzuki S, Ishii Y, Watanabe N, Takahashi $\mathrm{T}$, Isokawa $\mathrm{K}$,et al. The p75 neurotrophin receptor regulates MC3T3-E1 osteoblastic differentiation. Differentiation. 2012 Dec;84(5):392-9.

2. Skaper SD1.Neurotrophic Factors: An Overview. 
Methods Mol Biol. 2018;1727:1-17.

3. Mogi M, Kondo A, Kinpara K, Togari A. Antiapoptotic action of nerve growth factor in mouse osteoblastic cell line. Life Sci. 2000;67(10):1197206.

4. Skaper SD. The biology of neurotrophins, signalling pathways, and functional peptide mimetics of neurotrophins and their receptors.CNS Neurol Disord Drug Targets. 2008 Feb;7(1):46-62.

5. Hankenson KD, Gagne K, Shaughnessy M..Extracellular signaling molecules to promote fracture healing and bone regeneration.Adv Drug Deliv Rev.2015; 1(94):3-12.

6. Sun CY, Chu ZB, She XM, Zhang L, Chen L, Ai LS,et al. Brain-derived neurotrophic factor is a potential osteoclast stimulating factor in multiple myeloma. Int J Cancer. 2012 Feb 15;130(4):82736.

7. Liu Y, Zhang X, Dai Y, Shu C, Qu P, Liu YX, et al. Effects of bone marrow mesenchymal stem cells on learning and memory functional recovery in neonatal rats with hypoxic-ischemic brain damage. Zhonghua Er Ke Za Zhi. 2008 Sep;46(9):648-53.

8. Krimm RF. Factors that regulate embryonic gustatory development.BMC Neurosci. 2007 Sep 18;8 Suppl 3:S4.

9. Kaplan DR, Miller FD. Developing with BDNF: a moving experience. Neuron.2007; 55:1-2.

10. Suzuki S, Dobashi Y, Hatakeyama Y, Tajiri R, Fujimura T, Heldin $\mathrm{CH}$, et al. Clinico-pathological significance of platelet derived growth factor (PDGF)-B and vascular endothelial growth factor-A expression, PDGF receptor- $\beta$ phosphorylation, and micro vessel density in gastric cancer. BMC Cancer. 2010 Nov 30; 10:659.

11. Su YW, Chung R, Ruan CS, Chim SM, Kuek V, Dwivedi PP, et al. Neurotrophin-3 Induces BMP2 and VEGF Activities and Promotes the Bony Repair of Injured Growth Plate Cartilage and Bone in Rats. J Bone Miner Res. 2016 Jun; 31(6):125874

12. Su YW, Chim SM, Zhou L, Hassanshahi M, Chung $R$, Fan $C$, et al. Osteoblast derived-neurotrophin-3 induces cartilage removal proteases and osteoclastmediated function at injured growth plate in rats. Bone.2018;116:232-247.

13. Park H, Poo MM. Neurotrophin regulation of neural circuit development and function. Nat Rev Neuro Sci .2013;14:7-23.

14. Lee SK1, Kim YS, Oh HS, Yang KH, Kim EC, Chi JG. Prenatal development of the human mandible. Anat Rec. 2001 Jul 1;263(3):314-25.

15. Su YW, Zhou XF, Foster BK, Grills BL, Xu $\mathrm{J}$, Xian CJ. Roles of neurotrophins in skeletal tissue formation and healing. J Cell Physiol.2018;233(3):2133-2145.

16. Kurihara H, Shinohara H, Yoshino H, Takeda K, Shiba H. Neurotrophins in cultured cells from periodontal tissues. J Periodontol. 2003 Jan; 74(1):76-84.

17. Chung R, Xian CJ.J. Recent research on the growth plate: Mechanisms for growth plate injury repair and potential cell-based therapies for regeneration. Mol Endocrinol.2014; 53(1):T45-61. 